\title{
乳児心不全患者のジゴキシン母集団薬物動態解析
}

\author{
末松文博 $\dagger^{1}$, 湯川栄二 $\dagger^{2}$, 峯本正夫 $\dagger^{1}$, 湯川美穂 $\dagger^{3}$, \\ 大戸茂弘 $\dagger^{2}$ ，樋口 駿 $\dagger^{2}$, 後藤良宣 $\dagger^{3}$

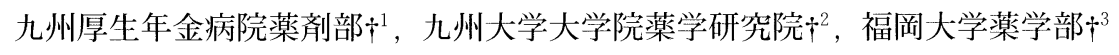

\section{Population Pharmacokinetic Analysis of Digoxin in Japanese Infants with Heart Failure}

\author{
Fumihiro Suematsu $\dagger^{1}$, Eiji Yukawa $\dagger^{2}$, Masao Minemoto $\ddagger^{1}$, Miho Yukawa $\dagger^{3}$, \\ Shigehiro Ohdo $\uparrow^{2}$, Shun Higuchi $\uparrow^{2}$ and Yoshinobu Goto $\uparrow^{3}$ \\ Department of Hospital Pharmacy, Kyushu Kousei-Nenkin Hospital $\dagger^{1}$ \\ Graduate School of Pharmaceutical Sciences, Kyushu University $\dagger^{2}$ \\ Faculty of Pharmaceutical Sciences, Fukuoka University $\dagger^{3}$
}

$\left[\begin{array}{l}\text { Received February 28, } 2001 \\ \text { Accepted July 12, } 2001\end{array}\right]$

\begin{abstract}
The steady-state concentrations of digoxin at trough levels were studied to establish the role of infant characteristics in estimating the doses for digoxin based on routine therapeutic drug monitoring data. The data $(\mathrm{n}=$ 340) which showed a steady-state after repetitive oral administration in 147 hospitalized infants were analyzed using NONMEM, a computer program designed to analyze the pharmacokinetics in study populations by allowing for the pooling of data. An analysis of the pharmacokinetics of digoxin was accomplished using a simple steady-state pharmacokinetic model. The effects of a variety of developmental and demographic factors on the clearance of digoxin were investigated. Estimates generated using NONMEM indicated that the clearance of digoxin $(\mathrm{L} / \mathrm{hr} / \mathrm{kg})$ was influenced by the demographic variables of age, the daily dose, serum creatinine, the presence or absence of congestive heart failure, and the coadministration of spironolactone in infants. The interindividual variability in the clearance of digoxin was modeled using proportional errors with an estimated coefficient of variation of $30.2 \%$, while the residual variability was $28.2 \%$.
\end{abstract}

Keywords - digoxin, infants, population pharmacokinetics, NONMEM, clearance

\section{緒言}

ジギタリス製剤であるジゴキシンは，うっ血性心不全 の治療薬として成人はもとより，小児領域に拈いても広 く用いられている。しかしながら，ジゴキシンは有効血 中濃度域も狭いうえ ${ }^{1)}$, 個体間変動が大きいため, 目標
とする血中濃度を得るための初期投与量設計が難しい薬 物である。このような薬物の体内動態を表す母集団パラ メータ (Population Pharmacokinetic Parameters) は投与 計画の基本情報であり，個々の患者に対し有効で安全な 薬物療法を行う上で重要となる。そのため, これまでに も日本人患者を対象としたジゴキシンの母集団解析につ

$\dagger^{1}$ 北九州市八幡西区岸の浦 2-1-1 ；2-1-1, Kishinoura, Yahatanishi-ku, Kitakyushu-shi, Fukuoka, 806-8501 Japan

$\dagger^{2}$ 福岡市東区馬出 3-1-1；3-1-1, Maidashi, Higashi-ku, Fukuoka-shi, 812-8582 Japan

$\dagger^{3}$ 福岡市城南区七隈 8-19-1；8-19-1, Nanakuma, Jonan-ku, Fukuoka-shi, 814-0180 Japan 
いての報告がなされているが2-4)，それらの多くは成人 を対象としたものであり，小児を対象とした報告はほと んどない.

そこで今回筆者らは，腎機能が未熟で体内動態が大き 〈変化する ${ }^{5)}$ 乳児を対象とし, 臨床で得られる断片的 なデー夕を利用してジゴキシンクリアランスを求め，そ れに影響を及ぼす生理的要因および個体差の程度につい て検討し, 投与計画への応用を試みたので報告する。

\section{対象と方法}

今回，九州厚生年金病院においてジゴキシン散を 1 日 2 回投与され，すでに定常状態に達している生後 1 力月 から 1 歳までの乳児心不全入院患者147名（測定点：340 点）を対象とした（表 1)。また，ジゴキシンの血中濃 度に影響を及ぼすことが知られている薬荗（スピロノラ クトンを除く）を併用している患者データは除外した。 血中濃度測定には, 試薬としてセディアージゴキシン II (山之内製薬 (株)）を用い, COBAS FARA（DAIDO 社） により行った。なお, 測定試薬の検出限界は0.2ng/ $\mathrm{mL}$, 変動係数 $(\mathrm{CV})$ は10\%未満であり, スピロノラクト ンとの交差反応は， $0.02 \%$ 未満 $(10 \mu \mathrm{g} / \mathrm{mL}$ 添加時 $)$ で ある。

患者群に対する体内動態解析には, Beal と Sheinerに よって開発されたコンピュータプログラム NONMEM を用いて行っだ).

薬物動態モデルとしては, 次の 1 ーコンパートメント モデル式を用いた.

$$
\mathrm{Css}_{\mathrm{ij}}=\mathrm{D}_{\mathrm{ij}} /\left(\mathrm{CL}_{\mathrm{ij}} \cdot \tau_{\mathrm{ij}}\right)
$$

ただし， $D_{\mathrm{ij}}$ は $\mathrm{j}$ 番目の患者の $\mathrm{i}$ 番目の投与量 $(\mu \mathrm{g}), \tau_{\mathrm{ij}}$ は $\mathrm{j}$ 番目の患者の $\mathrm{i}$ 番目の投与間隔 $(\mathrm{hr}), \mathrm{CL}_{\mathrm{ij}}$ はジゴキ シンクリアランス $(\mathrm{L} / \mathrm{hr})$ を示している。本来, $\mathrm{Css}_{\mathrm{ij}}$ は $\mathrm{j}$ 番目の患者の $\mathrm{i}$ 番目の平均血中濃度を用いなければな
らないが，臨床では投与直前に採血されることが多く， 今回は朝食前の最低血中濃度 $(\mathrm{ng} / \mathrm{mL})$ を用いた. $\mathrm{CL}_{\mathrm{ij}}$ に影響を与える生理的要因としては, 体重 (TBW : kg), 年歯 (AGE : days), 性別 (GEN), 血清クレアチニン值 $(\mathrm{Scr}: \mathrm{mg} / \mathrm{dL})$, 投与量 (DOSE : $\mu \mathrm{g} / \mathrm{kg} / \mathrm{day})$ を考慮し, また, 併用薬としてのスピロノラクトン (SPI) やうっ 血性心不全 (CHF) の影響についても検討した.

個体内 ·残差変動を表す誤差モデルは変動係数一定の正 規分布を仮定した。

$$
\mathrm{Css}_{\mathrm{ij}}=\tilde{\mathrm{Css}}_{\mathrm{ij}}\left(1+\varepsilon_{\mathrm{ij}}\right)
$$

ここで, $\operatorname{Css}_{\mathrm{ij}}$ は $\mathrm{j}$ 番目の患者の $\mathrm{i}$ 番目の予想される推定 血中濃度, $\varepsilon_{\mathrm{ij}}$ は平均 0 , 分散 $\sigma^{2}$ の確率変数であり, 測 定誤差・個体内変動・モデルからのズレに起因する誤差 の程度を表す。

$\mathrm{CL}_{\mathrm{ij}}$ の個体間変動を表す誤差モデルは変動係数一定の 正規分布を仮定した。

$$
\mathrm{CL}_{\mathrm{ij}}=\mathrm{CL}_{\mathrm{ij}}\left(1+\eta_{\mathrm{ij}}\right)
$$

ここで, $\tilde{C} L_{\mathrm{ij}}$ は $\mathrm{j}$ 番目の患者の $\mathrm{i}$ 番目の予測される推定 パラメータ, $\eta_{\mathrm{ij}}$ は平均 0 , 分散 $\omega^{2}$ の確率変数を表 す.

\section{NONMEM 解析}

各要因を考慮しないBasic model に対し, 患者の要因 を一つずつ組み込んでいき, 目的関数の差（LLD： - $2 \cdot \log$ likelihood difference) により影響の有無を判定 した。なお，LLDは $\chi^{2} の$ 分布に近似されるので，パラ メータの数が 1 つ増えた場合, LLDが自由度 1 の $\mathrm{P}=$ 0.05の值（3.841）より大きい時, 有意であると判定し た. また，モデル化した各影響因子の効果については尤 度比検定にて判定した。すなわち，パラメータを帰無仮 説值に固定した時の LLD が3.841より大きい場合，その パラメータは有意であると判定した。

表 1 . 患者データ

\begin{tabular}{lcc}
\hline & 母集団解析 & 精度評価 \\
\hline 患者数 & 147 & 54 \\
測定点 & 340 & 66 \\
SPI $(+)$ & 284 & 55 \\
CHF $(+)$ & 185 & 48 \\
年齢 $($ days $)$ & $107.6 \pm 79.7(31 \sim 362) *$ & $108.4 \pm 90.1(31 \sim 362) *$ \\
体重 $(\mathrm{kg})$ & $3.93 \pm 1.38(1.49 \sim 9.65) *$ & $4.25 \pm 1.47(2.21 \sim 8.21) *$ \\
投-与量 $(\mu \mathrm{g} / \mathrm{kg} / \mathrm{day})$ & $9.31 \pm 2.08(3.82 \sim 15.72) *$ & $9.78 \pm 1.95(4.76 \sim 13.30) *$ \\
血中濃度 $(\mathrm{ng} / \mathrm{mL})$ & $0.80 \pm 0.36(0.24 \sim 1.99)^{*}$ & $0.82 \pm 0.33(0.29 \sim 1.83) *$ \\
\hline
\end{tabular}

*: 平均値士SD, 括弧内は範囲 
さらに，投与計画の必要な乳児54名（測定点：66点） にNONMEM 解析より得られた平均 CL を用いて，投与 量に対する最低血中濃度を予測した。予測精度の評価 は，予測誤差 (予測值一実測值) の平均 (ME) および予 測誤差の絶対值の平均 (MAE) により行った7). なお, 表 1 に示したように，母集団解析に用いた患者群と予測 精度評価に用いた患者群との間に，有意差はなかった (MannWhitney U-test).

\section{結果}

図 1 にジゴキシン投与量に対する血中濃度を示した が，散布図のばらつきは大きく，投与量から血中濃度を ただちに予測することは困難である。

そこでまずはじめに，NONMEM 解析を行うための基 礎的検討として, 各種生理的要因と, 式 1 より算出した

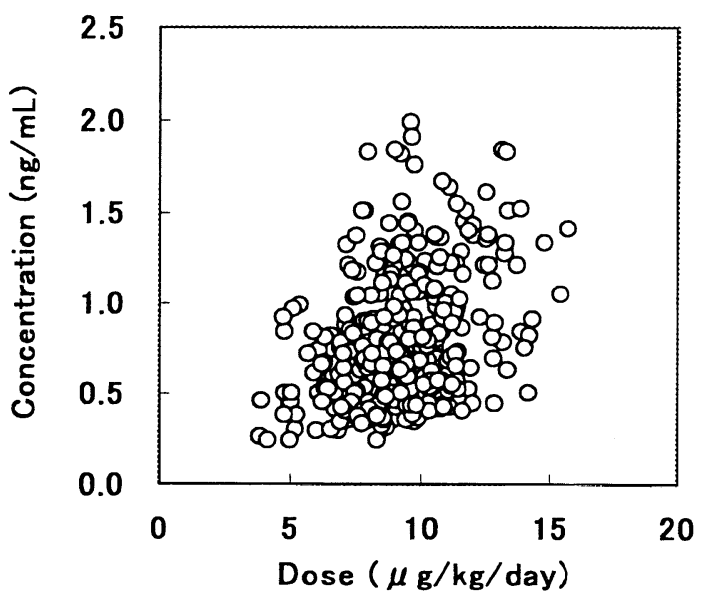

図 1.ジゴキシン投与量に対する血中濃度

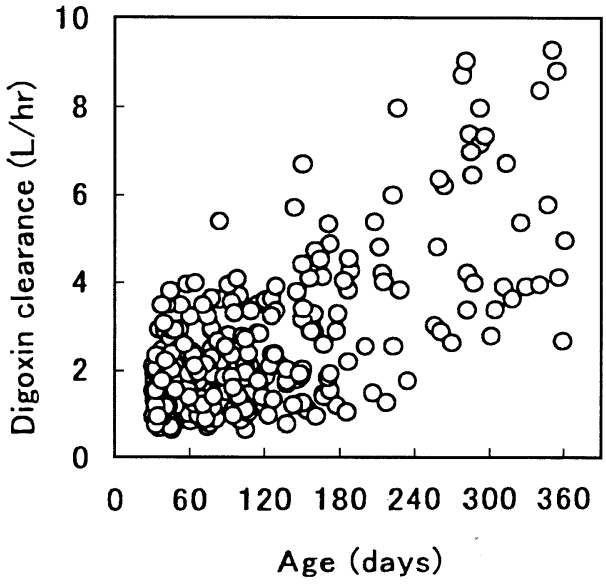

CLとの関係を散布図を用いて検討した。図 2 に年齢お よび体重に対するCLをプロットした散布図を示した が，これより，体重に対してやや正の相関が認められる ものの，散布図はいずれも大きなばらつきが認められ た。このことより，個々の生理的要因からだけでは， CL を予測することは困難であることがわかった。

\section{NONMEM 解析}

クリアランスになにも要因を考慮しない Basic model に対し，患者の要因を 1 つずつ組み込んでいき，目的関 数の差より，要因の影響の有無を判定した（表 2 ). そ の結果，体重，年齢，投与量，Scr 值，CHF の有無，な らびにSPI 併用の影響が認められた。そして，この中間 モデルにおいて，有意差の認められた各要因を組み合わ せて，次に示す Full model を構築した。

$\mathrm{CL}(\mathrm{L} / \mathrm{hr})=\theta_{1} \cdot \mathrm{TBW}^{\theta 2} \cdot \mathrm{AGE}^{\theta 3} \cdot \mathrm{DOSE}^{\theta 4} \cdot \mathrm{Scr}^{\theta 5} \cdot$ $\theta_{6}^{\mathrm{CHF}} \cdot \theta_{7}^{\mathrm{SPI}}$

(式 4)

さらに, Full modelに対し帰無仮説検定を行った結果 (表 3 )，式 5 に示した最終モデル式が得られた(表 4 ).

$\mathrm{CL}(\mathrm{L} / \mathrm{kg} / \mathrm{hr})=0.157 \cdot \mathrm{AGE}^{0.0866} \cdot \mathrm{DOSE}^{0.316} \cdot \mathrm{Scr}^{-0.173} \cdot$ $0.867^{\mathrm{CHF}} \cdot 0.877^{\mathrm{SPI}}$ （式 5 ）

なお, 式 5 における個体間変動は $30.2 \%$ であり, 残差変 動は28.2\%であった。

\section{2. 予測精度評価}

最終的に得られた乳児の平均 CL 式を用いて，新たな 乳巟群に対して，定常状態における朝服薬前の血中濃度 の予測を行った。その結果, 予測の偏り (bias)の指標と なる平均予測誤差 $(\mathrm{ME})$ は， $0.02 \pm 0.24 \mathrm{ng} / \mathrm{mL}$ ，予測の 正確さ (accuracy)の指標となる絶対予測誤差 (MAE)

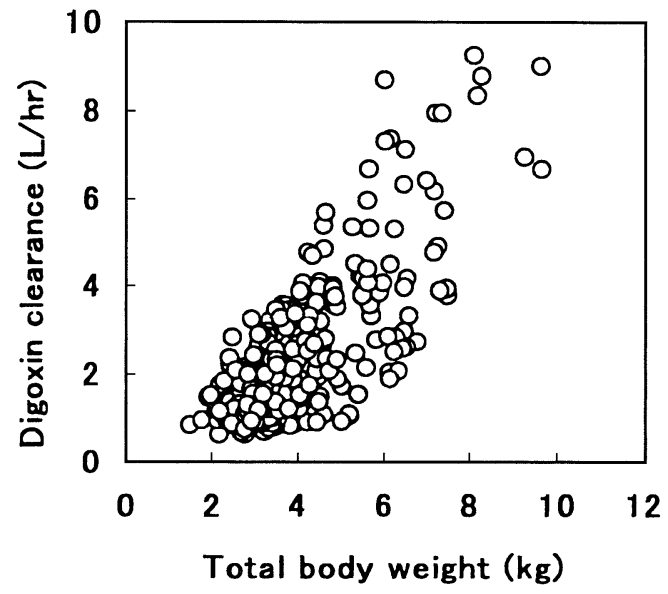


表 2. 乳児を対象とした NONMEM 解析より得られた母集団パ

ラメータ值と目的関数の值

\begin{tabular}{|c|c|c|c|c|c|}
\hline & 式 & OBJ & LLD & $P$ value & 判定 \\
\hline Basic model & $\begin{array}{l}C L=\theta_{1} \\
\theta_{1}=1.72 \\
\omega_{C L}=42.7 \% \quad \sigma_{E}=33.0 \%\end{array}$ & -337.790 & & & \\
\hline 体重はＣＬに影響するか？ & $\begin{array}{l}C L=\theta_{1} \cdot T B W \theta_{2} \\
\theta_{1}=0.431 \quad \theta_{2}=1.08 \\
\omega_{C L}=35.5 \% \quad \sigma_{E}=28.2 \%\end{array}$ & -477.721 & 139.931 & $<0.001$ & yes \\
\hline 年齢はＣＬに影響するか？ & $\begin{array}{l}C L=\theta_{1}, A G E \theta_{2} \\
\theta_{1}=0.326 \quad \theta_{2}=0.384 \\
\omega_{C L}=40.5 \% \quad \sigma_{E}=30.3 \%\end{array}$ & -419.402 & 81.612 & $<0.001$ & yes \\
\hline 投与量はＣＬに影響するか？ & $\begin{array}{l}C L=\theta_{1}, \quad \text { DOSE } \theta_{2} \\
\theta_{1}=1.10 \quad \theta_{2}=0.203 \\
\omega_{C L}=41.8 \% \quad \sigma_{E}=33.2 \%\end{array}$ & -342.386 & 4.596 & $<0.05$ & yes \\
\hline ScrはＣＬに影響するか？ & $\begin{array}{l}C L=\theta_{1} \quad \cdot \operatorname{Scr} \theta_{2} \\
\theta_{1}=1.31 \quad \theta_{2}=-0.192 \\
\omega_{C L}=42.8 \% \quad \sigma_{E}=32.4 \%\end{array}$ & -346.019 & 8.229 & $<0.01$ & yes \\
\hline 性別はＣＬに影響するか？ & $\begin{array}{l}C L=\theta_{1} \cdot \theta_{2} \text { GEN } \\
\theta_{1}=1.76 \quad \theta_{2}=0.953 \\
\omega_{C L}=42.9 \% \quad \sigma_{E}=32.9 \%\end{array}$ & -338.498 & 0.708 & $>0.5$ & no \\
\hline C H F の有無はC L に影響するか? & 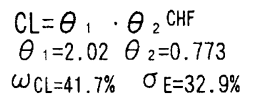 & -360.244 & 22.454 & $<0.001$ & yes \\
\hline S P I の併用はC L に影響するか? & $\begin{array}{l}C L=\theta_{1} \cdot \theta_{2} S P I \\
\theta_{1}=1.95 \quad \theta_{2}=0.861 \\
\omega_{C L}=41.5 \% \quad \sigma_{E}=33.0 \%\end{array}$ & -345.125 & 7.335 & $<0.01$ & yes \\
\hline
\end{tabular}

OBJ: NONMEMより算出された目的関数の値.

LLD: 目的関数の差 $(-2 l o g$ likelihood difference $)$.

表 3. Full model に対する帰無仮説検定

\begin{tabular}{|c|c|c|c|c|}
\hline Hypothesis & educed model & LLD & $P$ value & 判定 \\
\hline 体重はＣＬに影響するか？ & $T B W \theta=0$ & 61.448 & $<0.001$ & yes \\
\hline 体重は非線形で C L に影響するか? & ? $\quad \operatorname{TBW} \theta=1$ & 3.279 & $>0.05$ & no \\
\hline 年齢はＣＬに影響するか？ & $\operatorname{AGE} \theta=0$ & 11.091 & $<0.001$ & yes \\
\hline 投-与量はＣＬに影響するか? & DOSE $\theta=0$ & 16.312 & $<0.001$ & yes \\
\hline ScrはC Lに影響するか? & $\operatorname{Scr} \theta=0$ & 7.885 & $<0.01$ & yes \\
\hline CHFの有無はC L に影響するか? & $\theta \mathrm{CHF}=0$ & 9.315 & $<0.005$ & yes \\
\hline S P I の併用はC L に影響するか? & $\theta S P I=0$ & 6.792 & $<0.01$ & yes \\
\hline
\end{tabular}

LLO: 目的関数の差 $(-2 \log l i k e l i h o o d$ difference $)$.

は, $0.19 \pm 0.14 \mathrm{ng} / \mathrm{mL}$ であった。

\section{考察}

母集団薬物動態解析では, 個体間変動を小さくする固 定効果を見つけ出し，モデル化することが重要な作業と なる.ジゴキシンの母集団パラメータについての報告と
して，1人の患者から経時的な数点の採血を行う Full screenによるものがある21.ただし，新生児や乳児を対 象とした場合, 採血自体のリスクが大きく, 経時的な複 数回の採血は極めて困難である. そのような時，2 点以 上のトラフ值（その中に1点しかない患者がいてもかま わない）を用いる Multiple trough screenが有用な手段 となる ${ }^{3,4)}$. 
表4. 母集団パラメータ

\begin{tabular}{ccl}
\hline Parameters & \multicolumn{2}{c}{ Estimates } \\
\hline$\theta_{1}$ & 0.157 & $(0.043 \sim 0.271)$ \\
$\theta_{2}$ & 0.0866 & $(-0.008 \sim 0.182)$ \\
$\theta_{3}$ & 0.316 & $(0.123 \sim 0.509)$ \\
$\theta_{4}$ & -0.173 & $(-0.300 \sim-0.046)$ \\
$\theta_{5}$ & 0.867 & $(0.745 \sim 0.989)$ \\
$\theta_{6}$ & 0.877 & $(0.754 \sim 0.999)$ \\
$\omega_{C L}(\%)$ & 30.2 & $(24.5 \sim 35.0)$ \\
$\sigma_{E}(\%)$ & 28.2 & $(23.9 \sim 31.9)$
\end{tabular}

$\mathrm{CL}=\theta_{1} \cdot \mathrm{TBW} \cdot \mathrm{AGE} \theta_{2} \cdot \mathrm{DOSE} \theta_{3} \cdot \mathrm{Scr} \theta_{4} \cdot \theta_{5}{ }^{\mathrm{CHF}} \cdot \theta_{6}{ }^{\mathrm{SPI}}(\mathrm{L} / \mathrm{hr})$ CHF， 1:CHF有り $0: C H F$ なし SPI，1:SPI併用 0:SPI非併用

\section{括弧内は、95\% confidence interval.}

今回われわれが行った, Multiple trough screenの手法 を用いた母集団解析の結果，乳児のジゴキシンクリアラ ンスに対し, 年齢, 体重, 投与量, Scr 值, CHFの有 無，ならびにSPIの併用の有無が影響を及ぼしているこ とが明らかとなった。なお，体重に関しては，線形と非 線形の間に有意な差は認められなかった。

今回影響の認められた要因のうち，年齢の増加に対し て乳児の CL は非線形に増加する傾向が認められた。年 齢におけるパラメータの值は，0.0866と小さいが，同じ 体重でも，生後360日の乳児は生後30日の乳児に比べて CL が約 $24 \%$ 高いことが示唆される.

また，体重あたりの投与量の増加に従い，CL が非線 形に増加する傾向も認められた。今回，ジゴキシンクリ アランスを算出する際に，CLを実際にはバイオアベイ ラビリティ $(\mathrm{F})$ で除した $\mathrm{CL} / \mathrm{F}$ とて考えている.この ことから，特に吸収の悪い散剤を服用している乳児の場 合，投与量を増加することにより，散剤のバイオアベイ ラビリティが変化することも予想される。

ジゴキシンクリアランスに対し，成人患者における CHFの影響については，これまでにいくつかの報告が ある ${ }^{8,9)}$. CHFのある患者では心房細動の患者に比べて ジゴキシンの腎クリアランスが低下しており ${ }^{8)}$ ，また， Sheiner $ら^{9)}$ のジゴキシン母集団パラメータでも，クリア ランスにおいて CHFの有無によって分類されている. さらに，湯川ら ${ }^{4}$ は，日本の成人患者を対象とした NONMEM 解析の結果， CHF のある患者は CL が約 $19 \%$ 低下すると報告している. 今回の解析の結果から, 乳児 においても，やはり $\mathrm{CHF}$ のる患者は，ない患者に比 べて $13 \%$ 程度 CL が低下することが示唆された。

SPI との併用により CL が低下することについては，
成人を対象とした多くの報告がある ${ }^{10-12)}$ 。また，日本 の成人を対象としたものとしては，日本TDM学会母集 団パラメータ研究会 ${ }^{2)}$ の約 $13 \%$ ，湯川ら ${ }^{4)}$ の約 $10 \% \mathrm{CL}$ が低下するとの報告がある。今回の解析より，乳児にお いても成人と同様に，SPIを併用することで CL が $12 \%$ 程度低下することがわかった。

体内に取り达まれたジゴキシンは，未変化体として $75 \%$ が腎から排泄され，糸球体ろ過と尿細管分泌により 尿中に排泄される。近年，この尿細管分泌は近位尿細管 刷子縁膜に存在する $\mathrm{P}$ 糖蛋白質によって輸送されるこ とが見い出された ${ }^{13,14)}$. さらに，SPIを併用することで $\mathrm{P}$ 糖蛋白質との結合を阻害し，ジゴキシンの分泌を抑制 すると考えられている。 その他にも，SPIを併用する と, 測定法によっては交差反応により，測定値を過大評 価することがあるとの報告もある ${ }^{15,16)}$. 今回用いた測定 法は，SPIによる影響が少ないことから，SPI併用によ る今回の CLの低下は，P 糖蛋白質との相互作用による ものが主な原因と考えられる。

なお，生後 1 力月未満の新生児では，血液中に認めら れるジゴキシン様物質（DLIS）の影響で，血中濃度を 高く測定する恐れがあることが知られているが17,18)，今 回の対象患者は生後 1 力月以上の乳児であり, DLISの 影響は少ないものと判断した。

今回行った Multiple trough screen では, 得られる母集 団パラメータは相対的なクリアランスだけで，真のクリ アランスや分布容積などの情報は得られない.ただし， 今回のようにデータを集めることが難しい患者におい て，比較的容易に得られる臨床デー夕により母集団パラ メー夕を求めることができることは，極めて意義深い. さらに，今回得られた母集団パラメータに対して，新た な乳児データ (54名, 測定点：66点）を用いて行った予 測精度評価の結果からも，ややばらつきはあるものの， 実際の臨床における初期投与量設定には役立つものと思 われる。

最後に, 今回 NONMEM 解析より得られたパラメー 夕を用いて，乳児における最低血中濃度 $\mathrm{C}_{\mathrm{ss}}^{\mathrm{min}}$ を求めるた めの式を示す。

$\mathrm{C}_{\mathrm{ss}}^{\min }=\operatorname{Dose}(\mu \mathrm{g} / \mathrm{kg} /$ day $) /\left[0.157 \cdot \mathrm{AGE}^{0.0866}\right.$.

$\operatorname{DOSE}^{0.316} \cdot \mathrm{Scr}^{-0.173} \cdot 0.867^{\mathrm{CHF}} \cdot 0.877^{\mathrm{SPI}} \cdot$

$24(\mathrm{~L} / \mathrm{kg} /$ day $)]$

（式 6）

\section{引用文献}

1) J.G. Wagner, Appraisal of digoxin bioavailability and pharmacokinetics in relation to cardiac therapy, Am. Heart J., 88, 133-138(1974).

2) 堀了平, 宮崎勝已, 水柿道直, 緒方宏泰, 後藤光 
良, 市村藤雄, 安原䢐人, 谷川原祐介, 橋本征 也，小上淑子，三牧孝至，田中一彦，奥村勝彦， 五味田裕, 樋口駿, 日本人における薬物動態母集 団パラメータの推定（1）：ジゴシン, TDM 研 究, 11, 7-17 (1994).

3) E. Yukawa, H. Mine, S. Higuchi, T. Aoyama, Digoxin population pharmacokinetics from routine clinical data: role of patient characteristics for estimating dosing regimens. J. Pharm. Pharmacol.,44, 761-765(1992).

4) E. Yukawa, T. Honda, S. Ohdo, S. Higuchi, T. Aoyama, Population-based investigation of relative clearance of digoxin in Japanese patients by multiple trough screen analysis : an update, J. Clin. Pharmacol., 37, 92-100 (1997).

5) F. Suematsu, M. Minemoto, E. Yukawa, S. Higuchi, Population analysis for the optimization of digoxin treatment in Japanese paediatric patients, J. Clin. Pharm. Ther., 24, 203-208(1999).

6) S.L. Beal and L.B. Sheiner, "NONMEM user's guides", ed. by NONMEM Project Group, University of California at San Francisco, San Francisco, 1992.

7) L.B. Sheiner and S.L. Beal, Some suggestions for measuring predictive performance, J. Pharmacokinet. Biopharm., 9, 503-512(1981).

8) M.A.B. Naffs, C. van der Hoek, S. van Duin, G. Koorevaar, W. Schopman, J. Silberbusch, Decreased renal clearance of digoxin in chronic congestive heart failure, Eur. J. Clin. Pharmacol., 29, 249-252 (1985).

9) L.B. Sheiner, B. Rosenberg, W. Marathe, Estimation of Population characteristics of pharmacokinetic parameters from routine clinical data, J. Pharmacokinet. Biopharm., 5, 445-479(1977).
10) S. Waldorff, J.D. Andersen, N. Heeboll-Nielsen, O. G. Nielsen, E. Moltke, U. Sorensen, E. Steiness, Spironolactone-induced changes in digoxin kinetics, Clin. Pharmacol. Ther., 24, 162-167 (1978).

11) P.E. Fenster, W.D. Hager, M.M. Goodman, Digoxinquinidine-spironolactone interaction, Clin. Pharmacol. Ther., 36, 70-73(1984).

12) A. Hedman, B. Angelin, A. Arvidsson, R. Dahlqvist, Digoxin-interactions in man: Spironolactone reduces renal but not biliary digoxin clearance, Eur. J. Clin. Pharmacol., 42, 481-485(1992).

13) Y. Tanigawara, N. Okumura, M. Hirai, M. Yasuhara, K. Ueda, N. Kioka, T. Komano, R. Hori, Transport of digoxin by human P-glycoprotein expressed in a

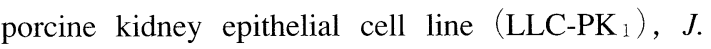
Pharmacol. Exp. Ther., 263, 840-845(1992).

14) R. Hori, N. Okumura, T. Aiba, Y. Tanigawara, Role of P-glycoprotein in renal tubular secretion of digoxin in the isolated perfused rat kindny, J. Pharmacol. Exp. Ther., 266, 1620-1625(1993).

15) J. Lichey, The effect of oral spironolactone and intravenous canrenoate- $\mathrm{K}$ on the digoxin radioimmunoassay, Int. J. Clin. Pharmacol. Biopharm., 15, 557559 (1997).

16) G.N. Foukaridis, Influence of spironolactone and its metabolite canrenone on serum digoxin assays, Ther. Drug Monit., 12, 82-84 (1990).

17) R. Valdes Jr, S.W. Graves, B.A. Brown, M. Landt, Endogenous substance in newborn infants causing false positive digoxin measurements, J. Pediatr., 102, 947-950 (1983).

18) R.P. Morris, W.S. David, E.J. Bery, F.W. Michael, Seven different immunoassay kits substance in serum from premature and full-term infants, Clin. Chem., 29, 1972-1974 (1983). 